\title{
Three curious dogs in a Dunhuang manuscript: re-evaluating the identification of "yaks" in Pelliot chinois 2598
}

\author{
Kelsey Granger \\ University of Cambridge, Cambridge, UK \\ K1394@cam.ac.uk
}

\begin{abstract}
A relatively understudied manuscript in the Pelliot collection, Pelliot chinois 2598 , features a drawing on its verso of three animals tentatively identified as yaks. However, I would like to re-identify these as being a particular kind of dog which appeared suddenly in the early Tang 唐 (618-907) dynasty. This case will be built on the visual correlations between this image and other descriptions and depictions of such dogs. The manuscript and drawing as a whole will also be explored to contextualize this depiction, which may in turn lead us to hypothesize about the existence, visually or physically, of these dogs and their associated tropes in Dunhuang 敦煌.
\end{abstract}

Keywords: Dunhuang, Manuscript studies, Tang-Song China, Dogs, Vaiśravana

A curious sketch on the verso of Dunhuang manuscript Pelliot chinois 2598, as given in Figure 1, features three animals previously misidentified as "yaks". 1 While at first glance very similar to a yak, I would like to argue for these three creatures to be identified as a specific type of dog. Through textual and artistic comparisons, I would like to assert that these are in fact representative of the same kind of dog which was prized in the Tang court. These small dogs, recorded as being introduced from abroad, marked a distinct change in accepted roles for dogs, being valued for their size, intelligence, and companionship, as opposed to skills related to hunting or guarding. ${ }^{2}$ I therefore hope to

1 The three dogs mentioned are tentatively identified as yaks in Catalogue des manuscrits Pelliot chinois 2501-3000 (Anon 2006, no. 2598). Eliasberg (1999: 224) also identifies these as yaks or snow-lions, though the latter identification is made equally tentatively. Figures given in this article are line drawings completed by the author. While great care has been taken to accurately replicate these drawings, minor discrepancies and human error must also be taken into consideration and the original manuscripts or paintings should be consulted if in any doubt. These are available online via the International Dunhuang Project catalogue, the Bibliothèque nationale de France's website, and the Liaoning Provincial Museum website respectively.

2 This delineation is made clear by the fact that these lapdogs are positioned with women, decorated with ribbons, and depicted in ways that emphasize their small size and playful personalities in sharp contrast to the ways in which hunting hounds and guard dogs are 


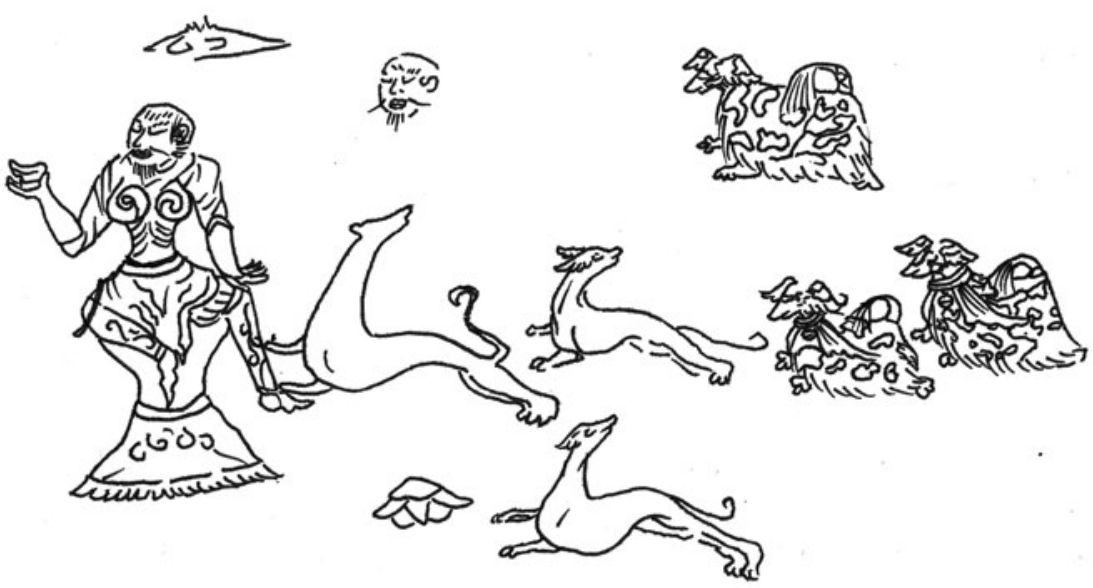

Figure 1. A line drawing completed by the author of the sketches on the verso of Pelliot chinois 2598 (Bibliothèque nationale de France, Paris). The original sketches were completed in ink, and the patches on the three animals on the far right, as well as the entire form of the left-most hound, were inked in.

prove that knowledge of these diminutive dogs existed in Dunhuang, as shown in this manuscript, and explore what conclusions and hypotheses may be drawn from this assertion.

Before looking at the manuscript as a whole or the wider context of these drawings, the identification of the three animals on the far right as yaks must first be brought into question. It should be immediately obvious that, unlike yaks, these animals clearly have paws instead of hooves. A yak or ox and a dog are illustrated on the verso of a further Dunhuang manuscript, Pelliot chinois 2622 , and the difference between hooves and paws is made clear both between these two figures and between the "yaks" in both manuscripts, as shown in Figure $2 .^{3}$

In order to clarify the exact identity of these three animals, the central group of dogs should first be identified. Clearly distinct in their presentation from those on the far right, these three dogs will be termed as hounds throughout. As this is a drawing, the scale of these animals both in real terms and in relation to each other is not clear. Indeed, the relative scale may not be reflective of reality at all. However, it is likely that these three hounds were actually reasonably large animals due to the striking parallels between them and Tang figurines of hunting hounds such as the greyhound or saluki.

shown. Depictions of lapdogs and guard dogs or hunting hounds are referenced throughout.

3 The verso, much like that of Pelliot chinois 2598, contains various writing exercises as well as drawings of the 12 calendrical animals, among which the image of an ox or yak and a dog are found. A further more detailed yak or ox with distinct hooves is also visible on the verso of Pelliot chinois 2702, as given in Eliasberg (1999: 200, fig. 3). 

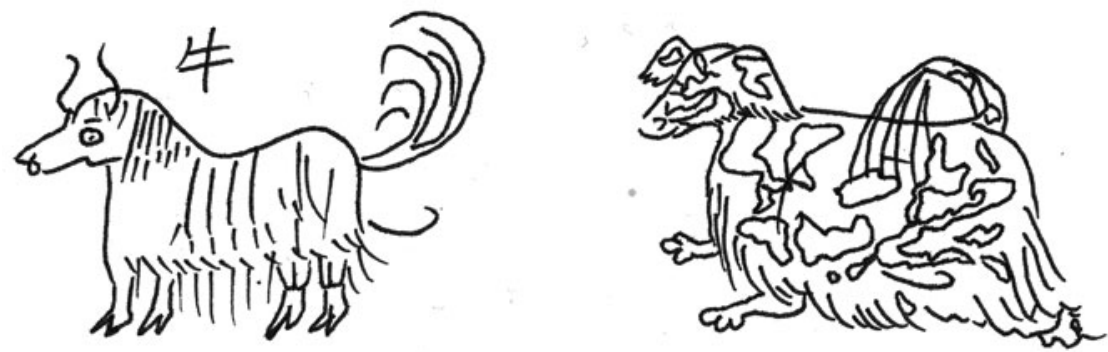

Figure 2. Line drawings completed by the author comparing the yak or ox from the verso of Pelliot chinois 2622 (Bibliothèque nationale de France, Paris) with one "yak" from the verso of Pelliot chinois 2598. The patches seen on the "yak" were originally inked in.

Ascribing exact breeds of modern dog onto ancient representations is flawed in many ways - dog breeds may not yet have developed into the form recognized today and may not have been as separate from each other as modern breeding programmes dictate. However, dogs with the distinctive ribcage of the broad greyhound category are evident even in Han 漢 $(206 \mathrm{BC}-220 \mathrm{CE})$ bas-reliefs, although it is not clear whether these animals were imported from the greyhound's original territory of Egypt or were a parallel strain of Chinese greyhound. ${ }^{4}$ By the Tang period, a further variation of this slim hunting hound can be seen in tomb art - the saluki, which is identified in Chinese art by its long-haired ears in place of the short ears of the greyhound..$^{5}$ The same distinctive ribcage and hollow stomach can also be seen in all three hounds in this manuscript, however only the two dogs to the right have long-haired saluki ears while the inked-in dog has greyhound-like ears, as is made clear in Figure 3.6

4 As discussed in Laufer (1909: 276-7). On greyhounds in Han art see, for instance, a line drawing of a Wuliang ancestral hall 武梁祠 bas-relief depicting a hunting scene in Jinshi suo 2: 1488-89, in which a collared greyhound is tethered by a hunter; a rubbing of a Xiaotang shan 孝堂山 bas-relief depicting hunting, as given in Chavannes (1913: P1. DIX no. 1222), where a greyhound is also collared and tethered by a hunter, as well as a line drawing of a further Wuliang ancestral hall bas-relief of a squatting greyhound (Chavannes 1893: Pl. XXV).

5 Welch 2018: 104. Examples of Tang tomb figurines of salukis include an earthenware collared saluki decorated with a white and green glaze which is dated to the seventheighth century: 29.18 (Metropolitan Museum of Art, New York, USA); a cream-coloured glazed pottery saluki sitting with its tail curled up against its side: DUROM.1992.100 (Durham University Museums, Durham, UK); and two moulded earthenware salukis dated to c. 660-689 which are sat looking sideways and forwards respectively: 923.24.104 and 923.24.83 (Royal Ontario Museum, Toronto, Canada). Examples of Tang tomb figurines of greyhounds include two moulded earthenware greyhounds dated to $c$. 650-675 in which the ears are noticeably shorter in length and placed higher on the dogs' heads than in the aforementioned depictions of salukis: 918.21 .884 and 923.17.112 (Royal Ontario Museum).

6 Eliasberg (1999: 225) identifies all three dogs as greyhounds, an identification which does not take into account the differences in ear length and shape discussed herein. 

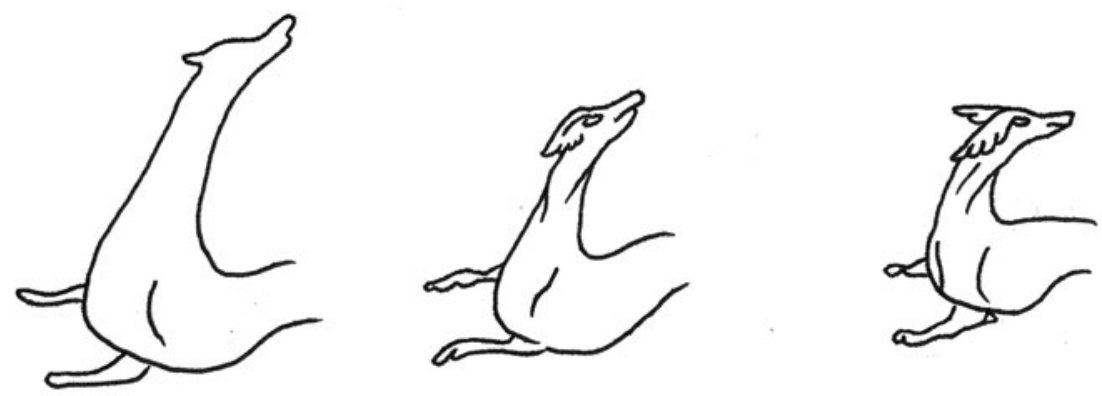

Figure 3. Line drawings completed by the author comparing the ears of the three hounds from the verso of Pelliot chinois 2598. The first has greyhound-like ears, while the other two have long-haired saluki ears. The greyhound was originally washed with ink. The placement, but not the size, of these hounds has been changed so as to better compare their respective ear shapes, and the original arrangement of these hounds can be seen in Figure 1.

The particular pose of fluid motion in this manuscript can also be seen in Han murals of greyhounds in hunting scenes. ${ }^{7}$ A standing saluki in a Tang mural displays a similar fluidity in its posing, and the overall similarities between greyhounds and salukis in tomb figurines and murals, as well as in this manuscript, suggest that both dog distinctions were used in hunting interchangeably. ${ }^{8}$

With this identification in mind, it is possible to contrast these depictions with the second group of dogs, the "yaks". These three animals clearly bear no similarities to the elongated, fluid poses of the nearby hunting hounds and have neither a distinct ribcage nor a hollow stomach. Should these be working dogs, then they may be engaged in the other major task related to dogs: guarding. Eastern Han 東漢 $(25-220 \mathrm{CE})$ tombs are replete with ceramic representations of guard dogs that may be compared with these three "yaks". 9 These ceramic tomb figurines usually depict dogs snarling or barking in the act of guarding, and nearly all known examples wear harnesses, implying that they were tethered. These harnesses also indicate that the dogs were of a large size and have even been

7 This can be seen in two Han rubbings of hunting scenes, the first from Henan 河南 and the second from Shandong 山東, which are given in Xia (1996: 80 [B17] and 86 [B22]). Both show complex scenes of armed hunters and hounds chasing down large prey such as deer, or smaller prey like hares and birds, with the greyhounds in the far left- and right-hand registers respectively showing great fluidity of movement.

8 This Tang mural is dated to 706 and was discovered in the tomb of Li Chongrun 李重潤 (682-701). The mural depicts a saluki next to a falconer who is possibly non-Chinese in light of his distinct facial hair and facial features, as photographed in Han Tang bihua (Anon 1974: 91).

9 For instance, two earthenware, green-glazed tomb figurines depict guard dogs wearing harnesses either snarling or open-mouthed: 1991.253.1 and 1994.605.18 (Metropolitan Museum of Art). Two further low-fired, lead-glazed ceramics depict open-mouthed guard dogs wearing harnesses: B60S205 and B60P306 (Asian Art Museum, San Francisco, USA). All of these items date to the Eastern Han period. 
associated with the mastiff category. ${ }^{10}$ Eastern Han ceramic figures of guard dogs can also have similar folded ears to those in this manuscript. ${ }^{11}$ However, the "yaks" lack the two defining features of stereotyped depictions of guard dogs in that they are not wearing harnesses and are not captured in a moment of warning or barking. Instead, two of these "yaks" are drawn wearing dangling ribbons with a bell, something not seen in depictions of guard dogs or indeed any pre-Tang dog. ${ }^{12}$

With no pre-Tang depictions of lapdogs, i.e. small dogs kept purely for pleasure and companionship, Tang official and unofficial histories, poetry, and paintings attest to the sudden arrival of small, intelligent dogs from abroad in the early Tang period. ${ }^{13}$ Firstly, Jiu Tangshu 舊唐書 (Old Book of Tang), Cefu yuangui 册府元龜 (Outstanding Models from the Storehouse of Literature), and Tongdian 通典 (Compendium of Institutions) all attest to the gifting of two diminutive dogs in 624 to Emperor Gaozu 高祖 (566-635, r. 618-626) by Gaochang 高昌 (Turfan), with the dogs apparently originating from Fulin 拂菻 (Byzantium). ${ }^{14}$ A further tale in Youyang zazu 西陽雜沮 (Miscellaneous Morsels from the Youyang Cave) tells of a dog from Kangguo 康國 (Samarkand) belonging to Yang Guifei 楊貴妃 (719-756), terming the dog wo 猧 (dwarf-dog). ${ }^{15}$ It is not yet clear whether the term wo refers to small dogs, lapdogs in a general sense, or a specific breed of lapdog. It is my belief that the answer lies somewhere between the latter two definitions, and as such I will henceforth use the terms wo and lapdog interchangeably.

Their marked intelligence and diminutive size, as well as potential overlaps with other exotic animals like parrots, meant that these imported small dogs were depicted alongside court women as beloved lapdogs in the late Tang period. The most famous example of this is Zanhua shinü tu 䙃花仕女图 (Ladies Wearing Flowers in Their Hair) attributed to Zhou Fang 周昉 (c. 730-800), in which the two diminutive dogs are similar to those in Pelliot chinois 2598 given their long hair, colouration, and hanging ribbons, as is shown in Figure 4. ${ }^{16}$

10 Laufer (1909: 263-4) identifies these specifically as Tibetan mastiffs. However, as with the aforementioned greyhounds, while these dogs may belong to the mastiff category it is difficult to ascertain their exact breed or subcategory.

11 This can be seen in the two examples from the Asian Art Museum which are given in note 9.

12 Some dogs are depicted wearing collars with or without bells - for instance, the aforementioned saluki (n. 8) is shown wearing a collar with a metallic disc which may potentially be a bell, while many greyhound-like dogs in the aforementioned Han murals (see n. 7) seem to be wearing collars without bells or discs attached. However, none of the examples that I have seen feature overly long dangling ribbons other than those mentioned in relation to lapdogs in this article.

13 These textual references are briefly explored by Schafer (1985: 77-8) who, together with Laufer (1909: 277-81), are the only Western Sinologists to have engaged with the topic of lapdogs in Chinese history.

14 Cefu yuangui 970.5a [11397], Jiu Tangshu 198.5294, Tongdian 191.5205; Fulin is equated with Byzantium in Yule 1916: 44.

15 Youyang zazu 1.2-3.

16 The date and artist of this piece are both subjects of frequent scholarly debate. However, as our focus lies with the dogs depicted rather than the context of the piece itself, these debates will not be explored further herein. Cf. Mei (2007) for a summation of prevalent theories regarding the dating of Zanhua shinü tu. 

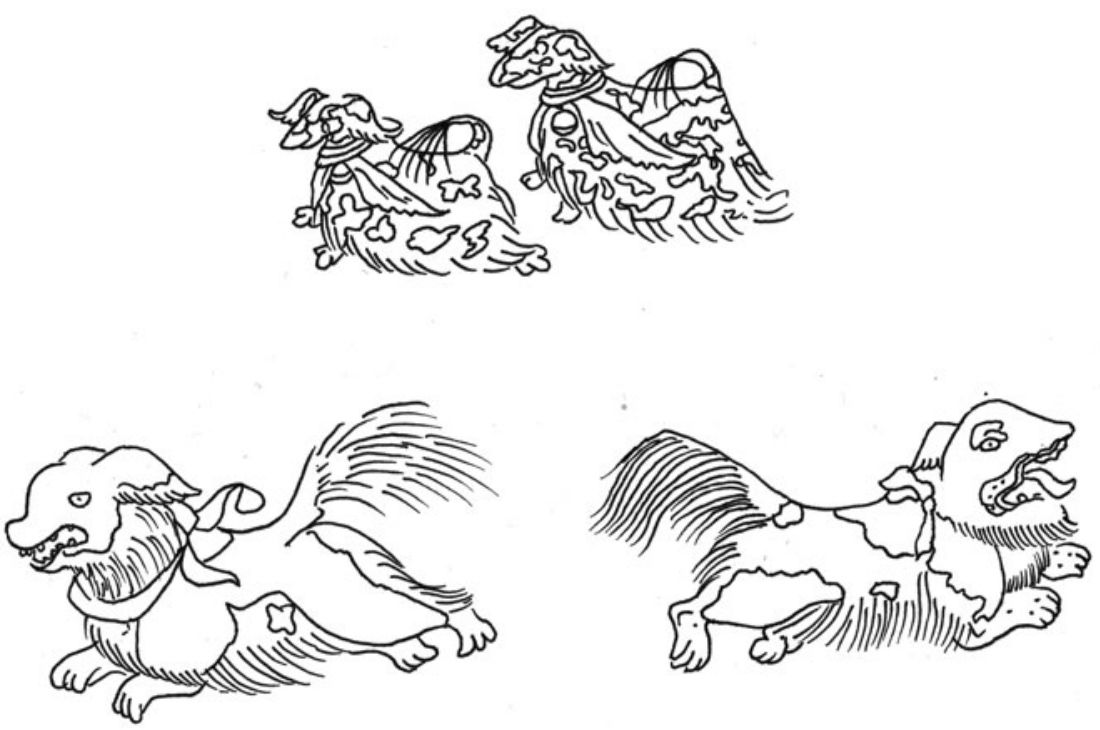

Figure 4. Line drawings completed by the author comparing the two "yaks" which wear ribbons with bells from the verso of Pelliot chinois 2598 with the two dogs from Zanhua shinü $t u$ 秠花仕女图 (Ladies Wearing Flowers in Their Hair), a piece completed in ink and colour on silk which was once a series of screen inserts then reassembled into a handscroll (Liaoning Provincial Museum, Shenyang). The two dogs from this painting were originally coloured with light pink ribbons and brown and white fur. They are drawn side by side here but are separated in the original composition.

The use of ribbons with bells is also associated with lapdogs in poetry in the Northern Song 北宋 (960-1126) period, with a dog named Taohua 桃花 (Peach-blossom) being described as such:

\section{宮中有犬桃花名，綘繒圍頸懸金鈴。17}

In the palace there was a dog named Taohua,

A metal bell hung from the deep red silk around its neck.

Clearly, the wearing of long ribbons and bells is synonymous with these diminutive wo in the art and literature of the Tang and Northern Song periods. So too do the recorded names of various wo suggest the patterned colouration of fur as seen in these three "yaks". This includes Huazi 花子 (Flowery or Patterned), Huaque 花鵲 (Flower-magpie or Patterned-magpie), and Taohua 桃花 (Peach-blossom), given that hua 花 can mean both "flower" and "dappled" or "patterned". 18

Thus, these three "yaks" should instead be identified as wo due to their physical appearance, colouration, and decoration. As previously discussed, the scale

17 “Taohua quan ge” 桃花犬歌 (“Song of the Dog Peach-blossom”) by Li Zhi 李至 (9471001) in Huangchao wenjian 13.3a-3b [Vol. 546].

18 Taiping guangji 386.3082, Sanshui xiaodu 1B.42, Huangchao wenjian 13.3a-3b [Vol. 546]. 
between these dogs and the nearby group of salukis and a greyhound does not necessarily mean that such dogs were of a similar scale - indeed, the depiction of wo in Zanhua shinü tu highlights their small size in relation to court women, as do further depictions of lapdogs alongside women in ceramics. ${ }^{19}$ Thus, if these three dogs may be said to represent the same diminutive, decorated lapdogs prized by court women in the Tang and Northern Song periods, what can we learn from their being depicted in Dunhuang?

First, the context of the manuscript itself must be taken into account. The recto features one juan of Xinji wenci jiujing chao 新集文詞九經鈔 (Newly Compiled Selections from the Nine Classics) copied by Yin Xianjun 陰賢君 with some of the beginning missing. This text is then followed by a few exercises including an improvised poem and the beginning of a letter. ${ }^{20}$ However, the poem and letter are of distinctly different hands to that of the copyist Yin Xianjun, implying that this manuscript was used by several people after Yin Xianjun's copying was completed. This seems to be in order of Yin Xianjun, the poet, and then the letter-writer, given the placement of each respective text. Had the order of ownership or use been different, we would expect the arrangement of writing to reflect this.

From the recto of Pelliot chinois 2598, it is already clear that this manuscript has been used by several people after Yin Xianjun copied one juan of Xinji wenci jiujing chao. The verso contains further fragments of texts, these drawings, an 873 colophon, and a colophon attributing the overleaf copying to Yin Xianjun in 883. Victor H. Mair gives these as being in "poor to very poor hands". ${ }^{21}$ The verso 883 colophon can be transcribed as follows:

\section{中和參四月十七日未侍 ( $\rightarrow$ 時) 書了。陰賢君書。}

In the third year of the Zhonghe (881-885) reign period, on the seventeenth day of the fourth month at the hour of wei, [this] was written. Yin Xianjun wrote [this]. ${ }^{22}$

The writing of this colophon is certainly of an inferior hand to Yin Xianjun's on the recto and therefore cannot be assumed to have been written by Yin Xianjun himself. This leaves the exact dating of his copying uncertain.

Other texts on the verso include the beginnings of association circulars, repetition of characters seemingly for practice, and writing exercises in various hands. While the beginning of the text is missing on the recto of Pelliot chinois 2598 , this is perhaps preserved on the rectos of Pelliot chinois 2557 followed

19 For instance, one painted ceramic features a plump Tang woman holding a small dog in her arms, emphasizing its small size in relation to the figure as a whole: GK 260 (Kyoto National Museum, Kyoto, Japan).

20 As described in Catalogue des manuscrits Pelliot chinois 2501-3000, Anon 2006, no. 2598].

21 Mair 1981: 15.

22 Altered from Mair 1981. 
more definitively by Pelliot chinois 3621 as these correlate with the missing text and are written in the same hand. ${ }^{23}$ These three pieces may then originally have been one manuscript - an assumption furthered by the fact that the verso of Pelliot chinois 3621 contains similar writing exercises and a partially completed drawing. ${ }^{24}$ Given the stark change in the quality of writing between the recto and verso in both Pelliot chinois 2598 and 3621, these drawings may not have been done by Yin Xianjun or in 883 . Who drew these, when they were drawn, and for what purpose therefore remains unclear. However, given the pragmatic nature of the various texts on the verso and the instructive nature of the text copied on the recto, this manuscript was probably the property of several students, perhaps lay students, and connected with an educational environment. ${ }^{25}$ As the copying of didactic texts by students with fragments of association circulars written on the verso is a particular feature of Guiyijun 歸義軍 (848-1036) Dunhuang manuscripts, this drawing can be considered to be part of a Dunhuang manuscript used by students from at least 873 until at least 883 .

Second, the drawing itself may also provide further information about why these wo were depicted. The drawing of both groups of dogs is accompanied by a seated figure on a pedestal as well as an incomplete drawing of a head and two other items above and to the lower left of this figure. The seated figure is an armour-clad male with an exaggerated breastplate and a sword at his belt. He is holding a cup aloft in one hand and seems to be seated on a pedestal placed on an ornate, fringed rug. The incomplete head seems to match that of the seated figure and so may have been a practice-run, further copy, or a later copy in another hand.

The seated figure may be compared with Zoroastrian and Buddhist images from the Dunhuang corpus in order to give further context to this drawing. The holding of a cup bears strong similarity to the iconography of Pelliot chinois 4518 no. 24, an ink painting which is often referred to as the Sogdian Deities sketch. In this manuscript, two female figures sit facing each other, with one

23 This case is made by Mair (1981: 15). Eliasberg (1999: 214, 225) also links Pelliot chinois 2598 and 3621 as originally being a single manuscript.

24 The verso of Pelliot chinois 2557 is not available on the International Dunhuang Project website. While the same text and hand, according to Mair, link what are now three separate manuscripts, there is a difference in the page layout between Pelliot chinois 2557 and the more similar Pelliot chinois 3621 and 2598. While the latter have ruled columns and margins, the writing in fact covers the entire sheet above and below the ruled margins. However, Pelliot chinois 2557 seems to show the writing staying within the parameters of the margins - although it is not clear whether these margins are closer to the edge of the folio or if the edges of the folio have been cut at some point to reduce a potentially larger gap between the margins and the edge of the folio. Furthermore, the ruled columns are sometimes not followed - a feature not seen in either Pelliot chinois 3621 or 2598 . The argument for connecting Pelliot chinois 3621 and 2598 as originally being one manuscript is well founded, but the addition of Pelliot chinois 2557 is somewhat more tenuous because of the different mise-en-page, as well as incongruities with regard to the actual size of the respective folios, with Pelliot chinois 3621 measuring $26-26.5 \mathrm{~cm} \times 51 \mathrm{~cm}$ and Pelliot chinois 2598 measuring a similar $25.4-26.9 \mathrm{~cm} \mathrm{x}$ $321 \mathrm{~cm}$ while Pelliot chinois 2557 measures $29.3-30.6 \mathrm{~cm}$ x $299.8 \mathrm{~cm}$. How Pelliot chinois 2557 relates to Yin Xianjun's copying as seen across the once-connected Pelliot chinois 3621 and 2598 is therefore still somewhat unclear.

25 Galambos 2016. 
holding a fluted cup or bowl in one hand and a small dog aloft on a dish in the other, while the opposite figure is seated on a large wolf-like animal. There has been much debate about which deities these female figures may represent, however the holding of a cup, seated position, and the presence of large and small dogs seem to parallel the broad themes of the drawing on Pelliot chinois $2598 .^{26}$

On the other hand, the holding of glass vessels and other such items can be associated with Buddhist deities, such as in painted banners of bodhisattvas. ${ }^{27}$ The figure in the cited banner from the British Museum bears more masculine features, such as facial hair, as well as a similar slender waist to that seen in Pelliot chinois 2598. Here, the glass-bowl not only represents one of the seven treasures of Buddhism but also alludes to the importation of glass into China from the Iranian world. ${ }^{28}$

Hunting hounds in particular are also linked with Buddhist imagery through the genre of soushan tu 搜山圖 (Picture of a Mountain Search) paintings. ${ }^{29}$ These may once have depicted symbolic hunts around Buddhist temples in Gaochang which were thought to remove harms, as described by Wang Yande 王延德 (939-1006) on his return to the Song court in 984. ${ }^{30}$ Indeed, one such non-extant painting was given to Emperor Taizong 太宗 (939-997, r. 976-997) in 976. ${ }^{31}$ A possibly similar example is seen in a mural from the north wall of the central chamber of Bezeklik Cave 20 in the tenth century. ${ }^{32}$ The mural in question depicts a slender hound biting a demon in the lower

26 This manuscript was excavated from Dunhuang's Mogao 莫高 caves and is dated to the tenth century. The identification of both figures and the various influences or references implied by the complex iconography of this piece have been a source of much scholarly scrutiny. For instance, Zhang (1994: 213-6) discusses the Sogdian roots of this image, in particular linking the four-armed figure seated on the wolf-like canine as being similar to Chorasmian depictions of the Sogdian deity Nana, and arguing that the sinicized way in which the sun and moon have been symbolized, i.e. as a three-legged crow in a red orb and a cinnamon tree in a clear orb, implies a Mazdean presence in the Dunhuang area. Following on from this, Grenet and Zhang (1996: 176-80) reassess this identification and conclude that the iconography of dogs as an offering and as a seat may instead reflect references in the Avesta to Dēn. Finally, Russell-Smith (2003: 404-5) gives examples of similar teardrop-shaped headdresses to these two figures in images from Bezeklik 柏孜克里. She summarizes that, while the clothing of both figures, brushstrokes, and paper used in Pelliot chinois 4518 no. 24 indicate local manufacture, both the Uyghur headdresses and similar iconography seen in Bezeklik implies an influence from Turfan Buddhist artwork on the composition of this piece.

27 One example is a painted silk banner depicting a bodhisattva holding a dimpled glass bowl which was excavated from the Thousand-Buddha Caves 千佛洞 in Dunhuang and which dates to c. 851-900: 1919,0101,0.139 (British Museum, London, UK).

28 Sasanian faceted glass was traded across Eurasia. These kinds of bowls are shown in Dunhuang murals, many of which are clearly Sasanian, and this may then indicate an overland route of transmission. Cf. An 2002.

29 Explored in Hinton 2016.

30 Songshi 490.14110-14112.

31 Tuhua jianwenzhi 3.5 b.

32 This mural is photographed in Zhao (1995: $91 \mathrm{pl}$. 88) and was destroyed in Berlin in the 1940s. On this mural, cf. Hinton 2016: 187. A further hound can be seen alongside Vaiśravana in another Bezeklik mural from the southern wall of the same chamber, photographed in Zhao (1995: $87 \mathrm{pl}$. 86). Both are identified as belonging to Cave 20 by Zhao, but as Cave 9 by Hinton. 
register of the scene while an armoured, armed figure marked by a halo stands in the upper register.

While various tianwang 天王 (Heavenly Kings) are depicted in this cave, many seem to correspond with the iconography of Bishamen Tianwang 毘沙 門天王 (Vaiśravana) of the North, who is likely the main figure of the aforementioned mural. ${ }^{33}$ The depiction of hunting hounds is also described with regard to non-extant images of Vaiśravaṇa, as can be seen in Yizhou minghua lu 益州名 畫錄 (Record of Famous Painters of Yizhou). This text was compiled by Huang Xiufu 黃休復 (dates unknown) in 1006 and gives his critique of several Tang and Song painters from the region, with the following excerpt describing a potential soushan tu scene painted by Sun Wei 孫位 (fl. 885-888):

\section{倣潤州高座寺張僧乿戰勝一堵。兩寺天王、部眾。人鬼相雜, 矛戟鼓 吹, 縱橫馳突, 交加戛擊, 欲有聲響。鷹犬之類, 皆三五筆而成, 弓 弦斧柄之屬, 並拶筆而描。34}

The monk Zhang of the Gaozuo temple in Fangrun prefecture commissioned [Sun Wei to paint] a mural of a battle scene. [He painted] the Heavenly King and Buddhist disciples of the two temples. People and demons were mixed up together bearing spears and halberds, drums and flutes, and charging horizontally and vertically. Their clashes and blows were on the verge of echoing sound. All those of the hawk and hound variety were completed in a few brush-strokes. All those of the bow-string and axe-handle type were depicted by [simply] picking up the brush.

Although Sun Wei's paintings of other Heavenly Kings designate their associated direction, as the content of the painting clearly matches with the soushan $t u$ genre, we can surmise that this was a depiction of Vaiśravana and was perhaps implicit enough not to warrant the added specification of his direction. ${ }^{35}$

Further depictions of this figure in Dunhuang materials attest to a standardized iconography in which he holds a stupa in his left hand and a standard in his right while wearing armour with a long sword at his belt. ${ }^{36}$ This can be seen in a standing image of Vaiśravaṇa from a 947 wood-block print, as well as in a seated image from the face of a relic box from the Famen temple 法門寺. ${ }^{37}$

33 As discussed in Hinton 2016: 188-92. On this deity in Indian, Central Asian, Tibetan, Chinese, and Japanese contexts, cf. Béguin and Colinart 1994: 139-40, Grenet 1995-96, and Williams 1973: 133-5.

34 Yizhou minghua lu 1A.1.

35 Yizhou minghua lu 1A.1-2.

36 The general iconography of this deity is explored in Williams (1973: 133) and representations found in the Dunhuang corpus are discussed in Soymié (1999: 30-36).

37 Dasheng Bishamen Tianwang 大聖毗沙門天王 (Wise Vaiśravaṇa) is a wood-block print dated to 947 excavated from Dunhuang's Thousand Buddha Caves. Vaiśravana, wearing armour and a long sword, stands holding a standard in his right hand and a stupa in his left. A child held in the background reflects a Khotanese legend associated with Vaiśravana, who was the patron deity of Khotan: 1919,0101,0.245 (British Museum). The gold on silver relic box from the Famen temple is dated to the eighth century and depicts a heavily armoured Vaiśravana sat with one leg perpendicular to the other and a long sword tied to his belt. As in the aforementioned British Museum wood- 
The seated position depicted on the relic box is very similar to that seen in this manuscript; however, the items held do not match. ${ }^{38}$

Further paintings show Vaiśravana holding the stupa and standard, sometimes a sword or halberd, in the opposite hands, as seen in a ninth-century painting from Dunhuang, which could then loosely parallel the depiction in Pelliot chinois $2598 .{ }^{39}$ Nevertheless, Vaiśravana is usually accompanied either by a subjugated demon under his feet or a child in the background - the latter recalling a Khotanese legend associated with Vaiśravana, their patron deity. ${ }^{40}$ The seated figure here, while armoured with a long sword tied to his belt and potentially holding a stupa aloft in his right hand, does not have a standard in the other hand and is sat on a rug instead of atop a subjugated demon. Despite the fact that hunting hounds are linked with Vaiśravana, there is incorrect or missing iconography in this depiction, which may be because this figure was drawn from memory or because the student was unfamiliar with the exact iconography needed. Of course, this may not be Vaiśravana at all. A final possibility is that this may be an artist's sketch rather than the work of a student.

Following from Sarah Fraser's analysis of artists' sketches at Dunhuang, this may then be a preparatory drawing for a mural, serving as a reminder for "easily forgotten features and unusual characteristics", or a practice sketch, which were largely "random details and repetitions of the same parts". ${ }^{41}$

If this sketch were a preparatory drawing for a mural then we may see traces of similar canine iconography in extant murals from the Mogao caves. However, there are very few instances of dogs among these murals and none which correspond even remotely with the three "yaks". One slender, red-furred dog with a long curled tail can be seen on the western side of the southern wall in Cave 459 and dates to the late Tang period. ${ }^{42}$ Being part of a larger scene on the anti-Buddhist acts of hunting and butchering animals based on Lengjia jingbian 楞伽經變 (Lañkāvatāra Sūtra), this dog must then be a hunting hound or at the very least a dog usually related with hunting. Its slender shape and overall fluidity is very similar to depictions of greyhounds and salukis discussed herein, although the shape of its ears is somewhat unclear. A further slender dog with grey and white colouration and distinct greyhound ears can also be seen in Cave $85 .{ }^{43}$ Positioned in a similar crouched pose, this dog has its head lowered to lie underneath a table. Since both dogs feature in larger scenes relating to the evils of hunting and butchering, their crouched posture can be interpreted as them waiting for the head of the butchered animal to fall. This reiterates the clear

block print, this seated Vaiśravana holds a stupa in his left hand and a halberd in his right: photographed in Yang 1999: 476.

38 As part of his cross-over with the Hindu deity of wealth Kuvera, Vaiśravana can also be depicted holding a golden mongoose. However, this does not seem to be the case here.

39 For instance, a ninth-century silk painting excavated from Cave 17 of the Thousand Buddha Caves in Dunhuang depicts Vaiśravana standing on a demon and holding a stupa in his right hand and a halberd in his left: 1919,0101,0.138 (British Museum).

40 Khotanese patronage is shown in Williams (1973: 114, 133).

41 Fraser 2000: 191.

42 This image is given in Dunhuang yanjiuyuan (2000: 131 fig. 117).

43 This image is also given in Dunhuang yanjiuyuan (2000: 131 fig. 118). 
association between greyhounds and salukis and acts of hunting in Chinese art. However, given the fact that their crouched position is so dissimilar to that seen in Pelliot chinois 2598 and that these dogs show no other similarities to the sketch in question, there is as yet no local mural that can be definitively linked with this manuscript.

Furthermore, it is the randomness of the figures in the drawing on Pelliot chinois 2598 that suggests it is an artist's sketch rather than a preparatory drawing for a mural, as Fraser summarizes:

In those [wall painting sketches], while space was collapsed, each figure had some thematic relation to the other figures. In these practice sketches there is little or no connection between [the subjects], other than an artist may have been working on paintings with these assorted topics at the same time. In the random, abbreviated mural sketches the drawing is loose and often very abbreviated; here many of the sketches are meticulously rendered $[\ldots]^{44}$

We can see that the drawings here are relatively complete and not "abbreviated". Furthermore, artists' sketches were often drawn on seemingly unrelated manuscripts, manuscripts Fraser takes as having been discarded. This seems to be the case with Pelliot chinois 2002 whose verso drawings bear no relation to the fire-damaged Wushang jinxuan shangmiao daode xuanjing 無上金玄上 妙道德玄經 Daoist text of the recto or to the context of the manuscript, nor do the drawings relate to each other. ${ }^{45}$

If the sketch on the verso of Pelliot chinois 2598 is thus a practice sketch as defined by Fraser then, much like the example of Pelliot chinois 2002, there are no intended parallels between the deity, hunting hounds, and the three wo. This assertion is also supported by the fact that, while there are some representations of Buddhist and Zoroastrian deities with such hounds, there are no known representations of wo alongside either subject. If we presume that the function of this manuscript as a student's copy was also, for some reason, expired, then we can speculatively date the sketches to post- 883 .

The depiction of three wo in this manuscript therefore attests to knowledge of these foreign animals in Dunhuang. This is in keeping with Tang records that refer to such dogs as coming from afar and as being given by foreign peoples - making it likely that traders of such dogs would have passed through Dunhuang on the overland silk routes. Such dogs may even have been bought and sold in Dunhuang itself. Thus, these three creatures are not yaks, but are instead three lapdogs depicted in an artist's sketch on a perhaps discarded student Dunhuang manuscript and which dates at the earliest to the late ninth century. These sketches do not necessarily mean that the artist personally viewed these diminutive dogs.

44 Fraser 2000: 221.

45 Fraser 2000: 90. The sketches on the verso of Pelliot chinois 2002 include scenes of wrestling, drawings of officials, and Buddhist imagery - some items being complete and others being isolated faces or body parts. Eliasberg (1999) presents further cases in which random and assorted drawings bear no relation to the context of the recto text and are also drawn in a different hand or hands. 
At this stage, we can only conclude that knowledge of these dogs and of the tropes associated with them clearly existed in Dunhuang.

\section{Bibliography}

\section{Primary sources}

Cefu yuangui 册府元龜. Wang Qinruo 王欽若 (962-1025) chief comp. Beijing: Zhonghua shuju, 1960.

Huangchao wenjian 皇朝文鑑. Lü Zuqian 呂祖謙 (1137-1181) chief ed. In Sibu congkan 四部叢刊, edited by Zhang Yuanji 張元濟 (1867-1959). Shanghai: Shangwu yinshuguan, 1929.

Jinshi suo 金石索. Feng Yunping 馮雲鵬 (dates unknown). Beijing: Shumu wenxian chubanshe, 1996.

Jiu Tangshu 舊唐書. Liu Xu 劉昫 (887-946) chief ed. Beijing: Zhonghua shuju, 1975.

Sanshui xiaodu 三水小牍. Huangfu Mei 皇甫枚 (841-911). Shanghai: Zhonghua shuju, 1958.

Songshi 宋史. Tuotuo 脫脫 (1313-1355) chief comp. Beijing: Zhonghua shuju, 1977.

Taiping guangji 太平廣記. Li Fang 李昉 (925-996) chief ed. Beijing: Renmin wenxue chubanshe, 1959.

Tongdian 通典. Du You 杜佑 (735-812). Beijing: Zhonghua shuju, 1988.

Tuhua jianwenzhi 圖畫見聞誌. Guo Ruoxu 郭若虛 (fl. 1070-1080). Shanghai: Shangwu yinshuguan, 1936 [1933].

Yizhou minghua lu 益州名畫錄. Huang Xiufu 黃休復 (dates unknown, work compiled 1006). Beijing: Renmin meishu chubanshe, 1964 [Collected with Si ta ji 寺塔記 and Yuandai huasu ji 元代畫塑記].

Youyang zazu 西陽雜沮. Duan Chengshi 段成式 (c. 803-863). Beijing: Zhonghua shuju, 1981.

\section{Secondary sources}

An, Jiayao. 2002. "When glass was treasured in China", in Annette Juliano and Judith Lerner (eds), Nomads, Traders and Holy Men along China's Silk Road, 7994. Turnhout: Brepols Publishers.

Anon. 1974. Han Tang bihua 漢唐壁畫 (Han and Tang Murals). Beijing: Wenwu chubanshe.

Anon. 2006. Catalogue des manuscrits Pelliot chinois 2501-3000. Paris: Bibliothèque nationale de France. Accessed via the International Dunhuang Project database.

Béguin, Gilles and Sylvie Colinart. 1994. "Vaiśravaṇa, Dieu des richesses, Dieu des armées: À propos d'un thang-ka du Musée Guimet", Artibus Asiae 54, no. 1/2, 137-55.

Chavannes, Édouard. 1893. La Sculpture sur pierre en Chine au temps des deux dynasties Han. Paris: E. Leroux.

Chavannes, Édouard. 1913. Mission Archéologique dans la Chine Septentrionale Vol. I: La Sculpture à l'Époque des Han. Paris: Ernest Leroux et Cie.

Dunhuang yanjiuyuan 敦煌研究院 ed. 2000. Dunhuang shiku quanji 敦煌石窟全集 (Complete Collection of the Dunhuang Grottoes) Vol. 19: Dongwu huajuan 動物 畫卷 (Paintings of Animals). Shanghai: Shanghai renmin chubanshe.

Eliasberg, Danielle. 1999. "Les graffiti figurés dans les manuscrits de Dunhuang", in Jean-Pierre Drège (ed.), Images de Dunhuang: Dessins et peintures sur papier des fonds Pelliot et Stein, 199-231. Paris: École française d'Extrême-Orient. 
Fraser, Sarah E. 2000. "Formulas of creativity: artist's sketches and techniques of copying at Dunhuang", Artibus Asiae 59, no. 3/4, 189-224.

Galambos, Imre. 2016. "Scribbles on the verso of manuscripts written by lay students in Dunhuang", Tonkō shahon kenykū nenpō 10, no. 3, 497-522.

Grenet, Frantz. 1995-96. "Vaiśravana in Sogdiana: about the origins of Bishamon-ten", Silk Road Art and Archaeology 4, 277-98.

Grenet, Frantz and Zhang Guangda 張廣達. 1996. “The last refuge of the Sogdian religion: Dunhuang in the ninth and tenth centuries", Bulletin of the Asia Institute New Series 10, 175-86.

Hinton, Carmelita. 2016. "Evil dragon, golden rodent, sleek hound: the evolution of Soushan Tu paintings in the Northern Song period", in Jerome Silbergeld and Eugene Y. Wang (eds), The Zoomorphic Imagination in Chinese Art and Culture, 171-214. Honolulu: University of Hawai'i Press.

Laufer, Berthold. 1909. Chinese Pottery of the Han Dynasty. Leiden: Brill.

Mair, Victor H. 1981. "Lay students and the making of written vernacular narratives: an inventory of Tun-huang manuscripts", Chinoperl 10, no. 1, 5-96.

Mei Liping 美麗平. 2007. “Chuan Zhou Fang 'Zanhua shinü tu' niandai wenti yanjiu xianzhuang” 傳周昉《篗花仕女圖》年代問題研究現狀 (“The current situation of studies on the time period of Zhou Fang's 'Ladies Wearing Flowers in Their Hair"'), Kezhi xinxi (kexue jiaojiu), no. 17, 392.

Russell-Smith, Lilla Bikfalvy. 2003. "Wives and patrons: Uygur political and artistic influence in tenth-century Dunhuang", Acta Orientalia Academiae Scientiarum Hung. 56, no. 2-4, 401-28.

Schafer, Edward H. 1985 [1963]. The Golden Peaches of Samarkand: A Study of T'ang Exotics. Berkeley: University of California Press.

Soymié, Michel. 1999. "Peintures et dessins de Dunhuang: Notes d'iconographie", in Jean-Pierre Drège (ed.), Images de Dunhuang: Dessins et peintures sur papier des fonds Pelliot et Stein, 13-54. Paris: École française d'Extrême-Orient.

Welch, Patricia. 2018. "The dogs of China: from utilitarian dogs to elegant hounds", Arts of Asia 48, no. 1, 102-11.

Williams, Joanna. 1973. "The iconography of Khotanese painting", East and West 23, no. $1 / 2,109-54$.

Xia Henglian 夏亨廉. 1996. Handai nongye huaxiang zhuanshi 漢代農業畫像磚石 (Han-era Agricultural Brick Portraits). Beijing: Zhongguo nongye chubanshe.

Yang, Xiaoneng (ed.). 1999. The Golden Age of Chinese Archaeology: Celebrated Discoveries from the People's Republic of China. Washington: National Gallery of Art.

Yule, Henry. 1916. Cathay and the Way Thither: Being a Collection of Medieval Notices of China, Vol. I. New Delhi: Munshiram Manoharlal Publishers Pvt. Ltd.

Zhang, Guangda 張廣達. 1994. “Trois exemples d'influences mazdéennes dans la Chine des Tang”, Études chinoises 13, no. 1-2, 203-19.

Zhao Min 趙每 (ed.). 1995. Zhongguo Xinjiang bihua quanji 中國新疆壁畫全集 (Complete Collection of Murals from Xinjiang) Vol. 6: Tuyugou Bozikelike 吐峪 溝柏孜克里克 (Tuyoq and Bezeklik). Shenyang: Liaoning meishu chubanshe. 